\title{
Antihyperlipidemic efficacy of aqueous extract of Stevia rebaudiana Bertoni in albino rats
}

\author{
Uswa Ahmad', Rabia Shabir Ahmad², Muhammad Sajid Arshad², Zarina Mushtaq ${ }^{2}$, Syed Makhdoom Hussain ${ }^{3}$ \\ and Aneela Hameed ${ }^{4}$
}

\begin{abstract}
Background: Stevia (Stevia rebaudiana Bertoni) natural, safe, non-toxic, non-caloric sugar substitute is rich source of pharmacologically important glycoside stevioside that is linked to the pathology and complications of hyperlipidemia.

Methods: The present research was carried out to explore the anti-hyperlipidemic effect of aqueous extract of Stevia rebaudiana Bertoni leaves in albino rats. For this purpose, hyperlipidemia was induced by administration of Cholesterol ( $90 \%$ E, Appli Chem, Darmstadt, Germany) mixed at dose of $400 \mathrm{mg} / \mathrm{kg}$ body weight of rats in their daily routine feed. The hyperlipidemic rats were administered with aqueous stevia extract at different dose levels $(200,300,400$ and 500 ppm/kg b.w.) for 8 weeks; the control rats were fed basal diet during this period. Ethical approval for the current research was obtained from Institutional Review Board Faculty of Science \& Technology Government College University, Faisalabad, Pakistan.
\end{abstract}

Results: Stevia aqueous extract decreased the body weight gain by lowering the feed intake of hyperlipidemic rats. Furthermore, administration of stevia extract at different levels significantly $(P<0.05)$ lowered the TC $(125.22 \pm 5.91$ to $110.56 \pm 5.81 \mathrm{mg} / \mathrm{dL}), \mathrm{TG}(102.13 \pm 6.89$ to $98.62 \pm 7.22 \mathrm{mg} / \mathrm{dL}), \mathrm{LDL}(33.02 \pm 4.79$ to $22.77 \pm 4.36 \mathrm{mg} / \mathrm{dL}), \mathrm{VLDL}$ ( $21.22 \pm 5.79$ to $19.33 \pm 5.95 \mathrm{mg} / \mathrm{dL}$ ) levels and $\mathrm{LDL} / \mathrm{HDL}$ ratios $\left(0.83 \pm 1.22\right.$ to $0.54 \pm 1.66 \mathrm{mg} / \mathrm{dL}$ ) from $\mathrm{H}_{1}$ to $\mathrm{H}_{4}$. Conversely, it improved the $\mathrm{HDL}(39.76 \pm 4.34$ to $142.02 \pm 4.39 \mathrm{mg} / \mathrm{dL})$ level in hyperlipidemic rats compared with untreated rats after eight weeks study period.

Conclusion: It is concluded that aqueous extract of stevia has anti-hyperlipidemic effects in albino rats, and therefore could be a promising nutraceutical therapy for the management of hyperlipidemia and its associated complications.

Keywords: Stevia rebaudiana Bertoni-Stevioside-hyperlipidemia

\section{Background}

Hyperlipidemia is a heterogeneous disorder characterized by an elevation of total cholesterol, triglycerides, very low density lipoprotein cholesterol, low-density lipoprotein cholesterol, free fatty acids and apolipoprotein B levels, as well as reduced high-density lipoprotein cholesterol levels [1]. Among these, hypercholesterolemia and hypertriglyceridemia are closely related to ischemic heart disease. Hyperlipidemia is a common predicament in society due to change of lifestyle and food practice. Proper diet

\footnotetext{
* Correspondence: rabiaahmad@gcuf.edu.pk

${ }^{2}$ Institute of Home and Food Sciences, Faculty of Science and Technology,

Government College University, Faisalabad 38000, Pakistan

Full list of author information is available at the end of the article
}

containing low fat, exercise and medication plays an important role in the prevention and treatment of increased lipid profile. Moreover, synthetic drugs are mostly used for the management of hyperlipidemia but consumption of these drugs for long period of time results in health problems such as diarrhea, liver and kidney problems due to their toxic effect. Therefore, people are more interested in using traditional medicinal plants due to their natural origin, safe and non-toxic nature [2]. Stevia rebaudiana Bertoni (family Asteraceae) popularly known as stevia, sweet weed, honey leaf and sweet herb of Paraguay [3]. It is natural, safe, non-toxic, non-calorie medicinal herb that has hypolipidemic ability due to presence of glycosides including stevioside, steviolbioside, rebaudiosides (A, B, C,

(c) The Author(s). 2018 Open Access This article is distributed under the terms of the Creative Commons Attribution 4.0 International License (http://creativecommons.org/licenses/by/4.0/), which permits unrestricted use, distribution, and 
D, E) and dulcoside A but the major sweet constituents are stevioside and rebaudioside A $[4,5]$. Natural non-caloric sweetener stevioside (a major component of stevia) is 100-300 times sweeter than sucrose and have been extensively used as a non-caloric sugar substitute in many kinds of foods, medicine, beverage, cosmetics, wine making, household chemical industry and other food industries [6]. Besides hypolipidemic effect, it also posses anti-hyperglycaemic, anti-hypertensive, anti-oxidant, antitumor, anti-diarrheal, diuretic, gastro- and renal-protective anti-viral and immunomodulatory properties [7]. The hypolipidemic effect of stevia has been proven in both humans and rats. According to previous literature $[8,9]$ stevia extract has ability to reduce total cholesterol, triglycerides, low density lipoprotein and very low density lipoprotein. Moreover, it increased the level of high density lipoprotein.

As the Stevia rebaudiana Bertoni is safe and non-toxic natural herb and can be a better alternative of synthetic medicines used for the treatment of hyperlipidemia. Hence, the current research was carried out to investigate the hypolipidimic potential of Stevia rebaudiana Bertoni in albino rats.

\section{Methods}

\section{Collection of material}

Stevia (Stevia rebaudiana Bertoni) leaves were collected from Ayub Agricultural Research Institute (AARI), Faisalabad, Pakistan.

\section{Procurement of raw material}

Stevia (Stevia rebaudiana Bertoni) leaves were washed to remove the dirt, dust and foreign material present on the surface. After washing, leaves of stevia were spread on trays and dried under shade at room temperature ranged from to $25-30{ }^{\circ} \mathrm{C}$ for $24-48 \mathrm{~h}$. Then dried leaves were grinded into fine powder with the help of grinder (MJ-176-NR-3899) [10].

\section{Preparation of stevia aqueous extract}

Stevioside was extracted from the dried ground stevia leaves by using water extraction. The dried ground leaves of stevia were mixed with hot water $\left(65^{\circ} \mathrm{C}\right)$ at the ratio of 1:45 $(w / v)$ and extracted for $3 \mathrm{~h}$. The crude extract containing stevioside were filtered through What man No. 1 filter paper and then evaporated to dryness by using rotary vacuum evaporator (EYELA N-1110 S 115 V) at $40-45{ }^{\circ} \mathrm{C}[11]$.

\section{Experimental animals}

Sixty adult male albino rats of average weight $153.88 \mathrm{~g}$ were purchased from National Institute of Health, Islamabad, Pakistan and kept in stainless steel cages under standard conditions (temperature $25 \pm 2{ }^{\circ} \mathrm{C}$ and $60 \pm 5 \%$ relative humidity with $12 \mathrm{~h}$ light-dark cycle) in environmentally controlled animal house of college of pharmacology, Faculty of Science and Technology, Government College University Faisalabad Pakistan. The rats were acclimatized by feeding freshly prepared basal diet containing $65 \%$ starch, $10 \%$ casein, $10 \%$ corn oil, $4 \%$ salt mixture, $1 \%$ vitamins mixture and $10 \%$ cellulose [12] and distilled water for two weeks.

\section{Induction of hyperlipidemia}

Hyperlipidemia was induced in albino rats with cholesterol (Cholesterol 90\% E, Appli Chem, Darmstadt, Germany) which was mixed at dose of $400 \mathrm{mg} / \mathrm{kg}$ body weight of rats in their daily routine feed. All the experimental groups were fed on high cholesterol feed (Normal rat feed + Cholesterol) for first 15 days. $\mathrm{H}_{0}$ (hyperlipidemic control group) was kept on high cholesterol feed while normal control group rats $\left(\mathrm{N}_{0}\right)$ fed on standard basal diet and distilled water throughout the experimental period (8 weeks) [13]. For the experiment stevia aqueous extract at the dose levels of 200, 300,400 and $500 \mathrm{ppm} / \mathrm{kg}$ body weight was dissolved in the distilled water of treated hyperlipidemic rats groups and given them orally with graduated feeding bottle on daily basis.

\section{Animal groups and experimental design}

Sixty male albino rats were divided into six groups of ten animals each and aqueous stevia extract was added in the distilled water of rats at different substitution levels given in Table 1.

\section{Physical parameters \\ Feed and water intake}

Net feed intake of individual rat was calculated on daily basis by excluding left-over and collected spilled diet during the entire period to determine the effect of individual experimental diet. Water was provided with the help of graduated drinking bottles and its consumption was also measured on daily basis.

\section{Gain in body weight}

Gain in body weight of individual rat in each group was estimated on weekly basis throughout the study period to find out the effect of treatments on body weight using electronic weighing balance (KERN 440-35 N).

\section{Collection of serum of rats}

After the 8 weeks of study period, the overnight fasted albino rats were killed using urethane anesthesia. The blood was collected by cardiac puncture and was centrifuged in the centrifuge machine (LABCENT 5000) at $3000 \mathrm{rpm}$ for $15 \mathrm{~min}$ after allowing the blood to stand for at least $30 \mathrm{~min}$ at room temperature as explained by [14]. 
Table 1 Diet plans for normal and hyperlipidemic rats

\begin{tabular}{|c|c|c|c|c|c|}
\hline \multirow{2}{*}{$\begin{array}{l}\text { Normal rats } \\
\mathrm{N}_{0}\end{array}$} & \multicolumn{5}{|l|}{ Hyperlipidemic rats } \\
\hline & $\mathrm{H}_{0}$ & $\mathrm{H}_{1}$ & $\mathrm{H}_{2}$ & $\mathrm{H}_{3}$ & $\mathrm{H}_{4}$ \\
\hline (Basal diet + distilled water) & $\begin{array}{l}\text { (High cholesterol } \\
\text { diet + distilled water) }\end{array}$ & $\begin{array}{l}\text { High cholesterol } \\
\text { diet }+200 \text { ppm SAE }\end{array}$ & $\begin{array}{l}\text { High cholesterol } \\
\text { diet+ } 300 \text { ppm SAE }\end{array}$ & $\begin{array}{l}\text { High cholesterol } \\
\text { diet }+400 \text { ppm SAE }\end{array}$ & $\begin{array}{l}\text { High cholesterol } \\
\text { diet + } 500 \text { ppm SAt }\end{array}$ \\
\hline
\end{tabular}

$\mathrm{N}_{0}=$ Basal diet and distilled water

$\mathrm{H}_{0}=$ High cholesterol diet and distilled water

$\mathrm{H}_{1}=$ High cholesterol diet and distilled water with 200 ppm Stevia leaf extract

$\mathrm{H}_{2}=$ High cholesterol diet and distilled water with $300 \mathrm{ppm}$ Stevia leaf extract

$\mathrm{H}_{3}=$ High cholesterol diet and distilled water with 400 ppm Stevia leaf extract

$\mathrm{H}_{4}=$ High cholesterol diet and distilled water with $500 \mathrm{ppm}$ Stevia leaf extract

\section{Serum lipid profile}

Serum lipid profile including total cholesterol, triglycerides, high density lipoproteins, low density lipoproteins, very low density lipoproteins and LDL/HDL ratio were measured by using auto chemistry analyzer (Rayto RT 9200) in order to observe the variation in plasma lipid profile due to administration of aqueous stevia extract according to their respective protocols. The detail of their procedures is given below:

\section{Total cholesterol level}

Serum cholesterol level was determined using CHODPAP method following the method of [15].

\section{Triglycerides level}

Total triglycerides in all serum samples were determined by liquid triglycerides (GPO-PAP) method as outlined by [16].

\section{High density lipoprotein level}

High density lipoprotein (HDL) in serum samples was measured by HDL Cholesterol Precipitant method as mentioned by [17].

\section{Low density lipoprotein and very low density lipoproteins levels}

Low-density lipoproteins (LDL) and very low-density lipoproteins (VLDL) levels were calculated by using the Friedewald formula [18] as follows:

$$
\begin{aligned}
& \mathrm{LDL}=\mathrm{TC}-(\mathrm{HDL}+\mathrm{VLDL}) \\
& \mathrm{VLDL}=\mathrm{TRIG} / 5
\end{aligned}
$$

\section{$L D L / H D L$ ratio}

Effect of stevia aqueous extract on LDL/HDL ratio of rats was also observed by dividing LDL and HDL.

\section{Statistical analysis}

The data regarding results of present research was statistically analyzed using mixed model (general linear model) by analysis of variance (ANOVA) using Minitab 17 software package. The level of significance between

the mean values of samples was determined by least significant difference (LSD) [19].

\section{Results}

Physical parameters

It is apparent from the results that different levels of stevia aqueous extract and study period (8 weeks) significantly affected feed intake, water intake and gain in body weight of normal and hyperlipidemic albino rats.

\section{Feed intake}

Mean values for feed intake in different groups of rats (g/rat/day) have been shown graphically in Fig. 1. The results demonstrated that administration of stevia sweetener reduced the feed intake in hyperlipidemic rats as compared to normal and hyperlipidemic groups. According to results feed intake of $\mathrm{N}_{0}$ and $\mathrm{H}_{0}$ increased from $16.72 \pm 1.28$ and $17.00 \pm 1.30 \mathrm{~g} / \mathrm{rat} / \mathrm{day}$ at $1 \mathrm{st}$ week to $18.32 \pm 1.76$ and $20.05 \pm 1.54 \mathrm{~g} / \mathrm{rat} /$ day respectively at 8 th week. In the case of stevia aqueous extract treated hyperlipidemic groups, the feed intake decreased as function of time and at 1st week feed intake in $\mathrm{H}_{1}, \mathrm{H}_{2}, \mathrm{H}_{3}$ and $\mathrm{H}_{4}$ was $16.22 \pm 1.14,15.87 \pm 1.43,15.12 \pm 1.04$ and $14.72 \pm$ $1.22 \mathrm{~g} / \mathrm{rat} /$ day that decreased to $14.20 \pm 1.02,13.62 \pm$

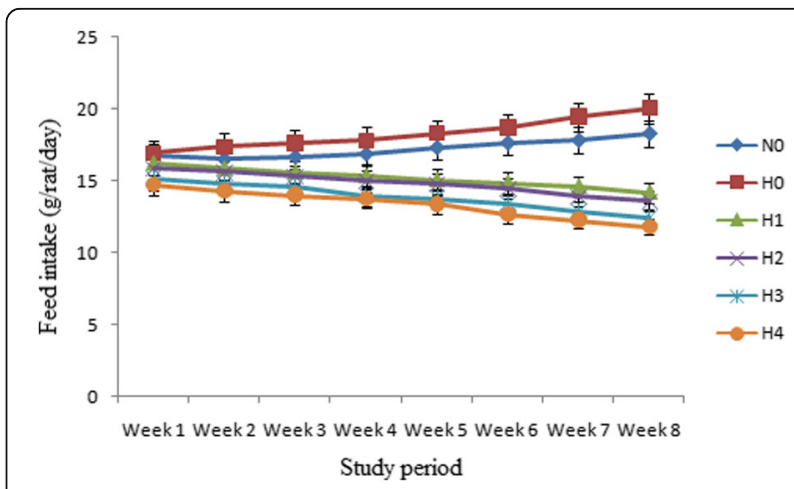

Fig. 1 Graphical presentation of feed intake ( $g /$ rat/day) in normal and hyperlipidemic rats after 8 weeks. Results are expressed as amount of feed intake levels of hyperlipidemic rats (mean \pm S.E.M., $n=10$ ) significantly $(P<0.05)$ different from normal and hyperlipidemic control groups 
$1.23,12.44 \pm 1.00$ and $11.82 \pm 1.32 \mathrm{~g} / \mathrm{rat} /$ day respectively at 8 th week.

\section{Water intake}

Means belonging to water intake as presented in Fig. 2, showed that at 1st week it was $27.7 \pm 1.01$ and $27.97 \pm$ $0.98 \mathrm{~mL} / \mathrm{rat} /$ day in $\mathrm{N}_{0}$ and $\mathrm{H}_{0}$ that increased to $29.21 \pm$ 0.34 and $30.62 \pm 1.04 \mathrm{~mL} / \mathrm{rat} /$ day, correspondingly at 8 th week. While in $\mathrm{H}_{1}, \mathrm{H}_{2}, \mathrm{H}_{3}$ and $\mathrm{H}_{4}$ the water intake decreased from $27.00 \pm 1.03,26.50 \pm 0.92,25.80 \pm 0.57$ and $25.22 \pm 0.87 \mathrm{~mL} / \mathrm{rat} /$ day at 1 st week to $25.32 \pm 0.99$, $24.7 \pm 0.87,24.15 \pm 0.45$ and $23.4 \pm 0.76 \mathrm{~mL} /$ rat/day at 8 th week respectively.

\section{Body weight gain}

Effect of administration of stevia sweetener on the weight gain in rats has been shown in Table 2. It is apparent from the results that the highest gain in body weight was observed in hyperlipidemic group $\left(\mathrm{H}_{0}\right)$ from $158.64 \pm$ $4.32 \mathrm{~g} / \mathrm{rat}$ at 1 st week to $195.26 \pm 4.50 \mathrm{~g} / \mathrm{rat}$ at 8 th week. While the lowest gain in body weight $(150.22 \pm 6.30$ to $124.77 \pm 7.80 \mathrm{~g} / \mathrm{rat}$ ) was observed in $\mathrm{H}_{4}$ (rats received $500 \mathrm{ppm} / \mathrm{kg}$ b.wt stevia aqueous extract) followed by $\mathrm{H}_{1}$, $\mathrm{H}_{2}$ and $\mathrm{H}_{3}$ from 1st to 8 weeks.

The results regarding body weight gain percentage (BWG \%) depicted that the highest BWG \% (26.95\%) was observed in $\mathrm{H}_{0}$. On the other hand, when hyperlipidemic rats were given stevia sweetener at doses of 200, 300, 400 and $500 \mathrm{ppm} / \mathrm{kg}$ b. wt then their body weight gain BWG \% decreased by $-13.58,-15.44,-17.89$ and $18.47 \%$ respectively after eight weeks (Table 3 ).

\section{Serum lipid profile}

\section{Total cholesterol level}

Table 4 shows that stevia aqueous extract significantly $(P<0.05)$ affected the total cholesterol levels of hyperlipidemic rats. The results found that highest value was

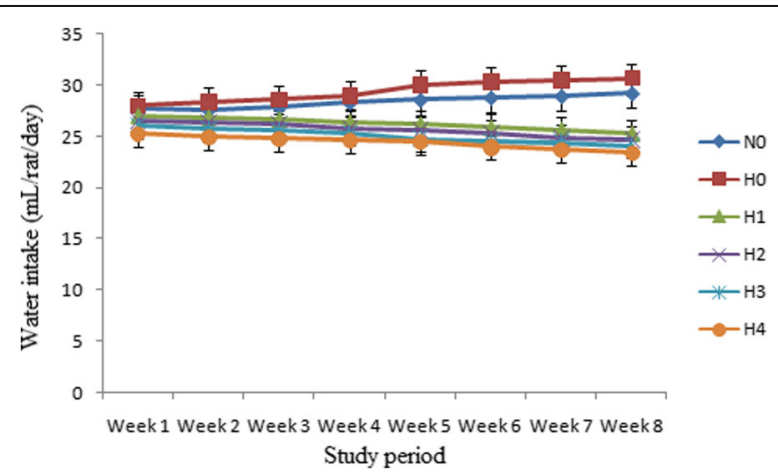

Fig. 2 Graphical presentation of water intake (mL/rat/day) in normal and hyperlipidemic rats after 8 weeks. Results are expressed as amount of water intake levels of hyperlipidemic rats (mean \pm S.E.M., $n=10$ ) significantly $(P<0.05)$ different from normal and hyperlipidemic control groups observed in hyperlipidemic group $\left(\mathrm{H}_{0}\right)(150.55 \pm 7.83 \mathrm{mg} /$ $\mathrm{dL})$. While total cholesterol of hyperlipidemic rats treated with stevia significantly reduced to $125.22 \pm 5.91 \mathrm{mg} / \mathrm{dL}$ in $\mathrm{H}_{1}, 121.63 \pm 56.81 \mathrm{mg} / \mathrm{dL}$ in $\mathrm{H}_{2}, 116.17 \pm 5.89 \mathrm{mg} / \mathrm{dL}$ in $\mathrm{H}_{3}$ and $110.56 \pm 5.81 \mathrm{mg} / \mathrm{dL}$ in $\mathrm{H}_{4}$. It is obvious from results that stevia aqueous extract decreased the cholesterol levels by $2.96,5.74,9.98$ and $14.32 \%$ in $\mathrm{H}_{1}, \mathrm{H}_{2}, \mathrm{H}_{3}$ and $\mathrm{H}_{4}$ when rats were given stevia sweetener at doses of 200, 300, 400 and $500 \mathrm{mg} / \mathrm{kg} / \mathrm{b}$. wt, respectively at eight weeks study period.

\section{Triglyceride level}

The mean values for triglyceride levels in normal and hyperlipidemic groups are given in Table 4 . The results confirmed that highest value of triglycerides was found in $\mathrm{H}_{0}(107.90 \pm 5.88 \mathrm{mg} / \mathrm{dL})$, while lowest value was observed in $\mathrm{H}_{4}(98.62 \pm 7.22 \mathrm{mg} / \mathrm{dL})$ followed by other groups $\left(\mathrm{H}_{1}, \mathrm{H}_{2}\right.$ and $\mathrm{H}_{3}$. It is confirmed from the results that triglycerides levels of hyperlipidemic rats received stevia aqueous extract at levels of 200,300, 400 and $500 \mathrm{mg} / \mathrm{kg} / \mathrm{b}$. wt in $\mathrm{H}_{1}, \mathrm{H}_{2}, \mathrm{H}_{3}$ and $\mathrm{H}_{4}$ decreased by $0.93,1.91,3.86$ and $4.33 \%$ respectively as compared to normal group $\left(\mathrm{N}_{0}\right)$ at eight weeks study period.

\section{High density lipoprotein level}

The mean values for HDL as presented in Table 4 showed that level of high density lipoprotein in hyperlipidemic rats was significantly affected by different levels of stevia aqueous extracts. According to results lowest value of HDL was observed in $\mathrm{H}_{0}$ while that value increased in $\mathrm{H}_{1}$ $(39.76 \pm 4.34 \mathrm{mg} / \mathrm{dL}), \mathrm{H}_{2}(40.13 \pm 4.74 \mathrm{mg} / \mathrm{dL}), \mathrm{H}_{3}(41.14 \pm$ $4.38 \mathrm{mg} / \mathrm{dL})$ and $\mathrm{H}_{4}(42.02 \pm 4.39 \mathrm{mg} / \mathrm{dL})$ with increasing the concentration of stevia aqueous extracts.

\section{Low density lipoprotein level}

The data presented in Table 4 indicated that low density lipoprotein (LDL) levels in hyperlipidemic rats were significantly $(P<0.05)$ affected by different levels of aqueous stevia extract. According to results, highest value for LDL was observed in $\mathrm{H}_{0}(55.49 \pm 3.88 \mathrm{mg} / \mathrm{dL})$, while lowest value was recorded in $\mathrm{H}_{4}(22.77 \pm 4.36 \mathrm{mg} / \mathrm{dL})$ as compared to $\mathrm{H}_{1}, \mathrm{H}_{2}$ and $\mathrm{H}_{3}$. Furthermore, the results revealed that $\mathrm{LDL}$ levels in $\mathrm{H}_{1}, \mathrm{H}_{2}, \mathrm{H}_{3}$ and $\mathrm{H}_{4}$ decreased by $6.56,12.50,21.27,35.56 \%$ respectively as compared to normal group $\left(\mathrm{N}_{0}\right)$ (Table 4).

\section{Very low density lipoprotein level}

Table 4 illustrated that very low density lipoprotein (VLDL) level in different groups of rats was considerably affected by treatments. The results confirmed that the highest value of VLDL was observed in hyperlipidemic group $\left(\mathrm{H}_{0}\right)$. However very low density lipoprotein levels of hyperlipidemic rats administrated with stevia decreased $(21.22 \pm 5.79 \mathrm{mg} / \mathrm{dL})$ in $\mathrm{H}_{1},(20.72 \pm 8.79 \mathrm{mg} / \mathrm{dL})$ in $\mathrm{H}_{2}$, 
Table 2 Effect of stevia aqueous extract on body weight ( $\mathrm{g} / \mathrm{rat}$ ) of hyperlipidemic and normal rats

\begin{tabular}{|c|c|c|c|c|c|c|c|c|}
\hline $\begin{array}{l}\text { Diet } \\
\text { groups }\end{array}$ & Week 1 & Weeks 2 & Weeks 3 & Weeks 4 & Weeks 5 & Weeks 6 & Weeks 7 & Weeks 8 \\
\hline$N_{0}$ & $156.28 \pm 4.00 \mathrm{Bh}$ & $160.38 \pm 5.75 \mathrm{Bg}$ & $164.14 \pm 8.12 \mathrm{Bf}$ & $168.16 \pm 9.20 \mathrm{Be}$ & $172.58 \pm 9.30 \mathrm{Bd}$ & $176.36 \pm 9.20 \mathrm{BC}$ & $181.38 \pm 5.4 \mathrm{Bb}$ & $\begin{array}{l}186.31 \pm \\
6.8 \mathrm{Ba}\end{array}$ \\
\hline $\mathrm{H}_{0}$ & $158.64 \pm 4.32 \mathrm{Ah}$ & $164.77 \pm 5.40 \mathrm{Ag}$ & $169.49 \pm 8.30 \mathrm{Af}$ & $174.46 \pm 8.77 \mathrm{Ae}$ & $179.64 \pm 9.11 \mathrm{Ad}$ & $185.02 \pm 7.90 \mathrm{Ac}$ & $190.42 \pm 4.3 \mathrm{Ab}$ & $\begin{array}{l}195.26 \pm \\
4.5 \mathrm{Aa}\end{array}$ \\
\hline $\mathrm{H}_{1}$ & $153.22 \pm 4.04 \mathrm{Ca}$ & $150.42 \pm 5.20 \mathrm{Ca}$ & $147.20 \pm 9.02 \mathrm{Cb}$ & $143.54 \pm 8.32 \mathrm{Cbc}$ & $140.89 \pm 9.20 C c$ & $138.76 \pm 8.78 \mathrm{Ccd}$ & $137.89 \pm 4.7 \mathrm{Cd}$ & $\begin{array}{l}134.55 \pm \\
4.42 \mathrm{Cd}\end{array}$ \\
\hline $\mathrm{H}_{2}$ & $152.30 \pm 6.30 \mathrm{Ca}$ & $149.21 \pm 4.30 \mathrm{Ca}$ & $145.43 \pm 8.44 \mathrm{Db}$ & $142.17 \pm 7.60 \mathrm{Dbc}$ & $138.54 \pm 8.62 \mathrm{Dc}$ & $135.43 \pm 9.24 \mathrm{Dcd}$ & $132.00 \pm 4.4 \mathrm{Dd}$ & $\begin{array}{l}130.22 \pm \\
4.50 \mathrm{Dd}\end{array}$ \\
\hline $\mathrm{H}_{3}$ & $151.42 \pm 5.80 \mathrm{Da}$ & $148.51 \pm 4.76 \mathrm{Da}$ & $144.21 \pm 5.06 \mathrm{Db}$ & $141.65 \pm 5.04 \mathrm{Dbc}$ & $137.32 \pm 7.44 \mathrm{Dc}$ & $134.65 \pm 8.99 \mathrm{Dcd}$ & $130.76 \pm 4.8 \mathrm{Ed}$ & $\begin{array}{l}126.48 \pm \\
6.12 \mathrm{Ed}\end{array}$ \\
\hline $\mathrm{H}_{4}$ & $150.22 \pm 6.30 \mathrm{Da}$ & $147.18 \pm 3.24 \mathrm{Da}$ & $144.45 \pm 5.02 \mathrm{Db}$ & $140.32 \pm 5.05 \mathrm{Ebc}$ & $135.76 \pm 6.65 \mathrm{EC}$ & $133.90 \pm 7.65 \mathrm{Ecd}$ & $129.22 \pm 4.60 \mathrm{Fd}$ & $\begin{array}{l}124.77 \pm \\
7.80 \mathrm{Fd}\end{array}$ \\
\hline
\end{tabular}

Values are mean \pm standard error $(n=10)$

Mean followed by different upper case letters in the same columns represent significant difference $(P<0.05)$ treatment wise

Mean followed by different lower case letters in the same rows represent significant difference $(P<0.05)$ among study periods $(8$ weeks)

$20.56 \pm 7.75 \mathrm{mg} / \mathrm{dL})$ in $\mathrm{H}_{3}$ and $(19.33 \pm 5.95 \mathrm{mg} / \mathrm{dL})$ in $\mathrm{H}_{4}$. The results depicted that stevia aqueous extract decreased the VLDL levels in $\mathrm{H}_{1}, \mathrm{H}_{2}, \mathrm{H}_{3}$ and $\mathrm{H}_{4}$ by $16.19,20.87$, 26.39 and $31.12 \%$ respectively as compared to normal group rats $\left(\mathrm{N}_{0}\right)$.

\section{LDL/HDL ratio}

The mean values for LDL/HDL ratios (Table 4) in normal and hyperlipidemic groups demonstrated that the highest value of LDL/HDL ratio was found in $\mathrm{H}_{0}(1.49 \pm$ $0.73 \mathrm{mg} / \mathrm{dL}$ ). However, lowest value of LDL/HDL ratio was observed in $\mathrm{H}_{4}(0.54 \pm 1.66 \mathrm{mg} / \mathrm{dL})$ followed by $\mathrm{H}_{1}$, $\mathrm{H}_{2}$ and $\mathrm{H}_{3}$.

Table 3 Means of initial body weight, final body weight and body weight gain \% in control groups rats and rats treated with different levels of stevia sweetener after 8 weeks

\begin{tabular}{llll}
\hline $\begin{array}{l}\text { Experimental } \\
\text { groups }\end{array}$ & $\begin{array}{l}\text { Initial body } \\
\text { weight (g) }\end{array}$ & $\begin{array}{l}\text { Final body } \\
\text { weight }(\mathrm{g})\end{array}$ & $\begin{array}{l}\text { Body weight } \\
\text { gain (\%) }\end{array}$ \\
\hline $\mathrm{N}_{0}$ & $152.70 \pm 2.32 \mathrm{a}$ & $186.31 \pm 6.80 \mathrm{~b}$ & $22.01 \mathrm{~b}$ \\
$\mathrm{H}_{0}$ & $153.80 \pm 3.04 \mathrm{a}$ & $195.26 \pm 4.50 \mathrm{a}$ & $26.95 \mathrm{a}$ \\
$\mathrm{H}_{1}$ & $155.70 \pm 3.65 \mathrm{a}$ & $134.55 \pm 4.42 \mathrm{c}$ & $-13.58 \mathrm{c}$ \\
$\mathrm{H}_{2}$ & $154.01 \pm 4.02 \mathrm{a}$ & $130.22 \pm 4.50 \mathrm{c}$ & $-15.44 \mathrm{~cd}$ \\
$\mathrm{H}_{3}$ & $154.05 \pm 4.70 \mathrm{a}$ & $126.48 \pm 6.12 \mathrm{~cd}$ & $-17.89 \mathrm{~d}$ \\
$\mathrm{H}_{4}$ & $153.05 \pm 4.44 \mathrm{a}$ & $124.77 \pm 7.80 \mathrm{~d}$ & $-18.47 \mathrm{~d}$ \\
\hline
\end{tabular}

Results are expressed as percentage of body weight gain of hyperlipidemic and normal rats (mean \pm S.E.R., $n=10$ )

$\mathrm{N}_{0}=$ Basal diet and distilled water

$\mathrm{H}_{0}=$ High cholesterol diet and distilled water

$\mathrm{H}_{1}=$ High cholesterol diet and distilled water with $200 \mathrm{ppm}$ aqueous stevia leaf extract

$\mathrm{H}_{2}=$ High cholesterol diet and distilled water with 300 ppm aqueous stevia leaf extract

$\mathrm{H}_{3}=$ High cholesterol diet and distilled water with $400 \mathrm{ppm}$ aqueous stevia leaf extract

$\mathrm{H}_{4}=$ High cholesterol diet and distilled water with 500 ppm aqueous stevia leaf extract

\section{Discussion}

The results regarding feed intake of different groups of rats found that $\mathrm{H}_{0}$ (Hyperlipidemic group) had higher feed intake due to high-fat diet given to them that increased their energy intake and energy storage [20]. While the hyperlipidemic rats that received stevia aqueous extract consumed less feed due to stevioside presence in it that may not stimulate the appetite of rats [21]. The results of current research work is supported by the findings of [22] who reported that stevia extract may reduced the feed intake because it is low-caloric sweetener that may not increase calorie intake and don't stimulate appetite. Furthermore, [1] demonstrated that Portulaca oleracea stem may reduce the feed intake of hyperlipidemic wister albino rats.

Water intake of hyperlipidemic rats reduced after administration of stevia aqueous extract due to glycoside (stevioside) in stevia extract that decreased the water consumption of rats. The findings of present study are in collaborations with work of [21] who illustrated that hyperlipidemic rats that received stevia aqueous extract consumed less water than control group rats (normal and hyperlipidemic). Afterwards, [1,22] found that stevia aqueous extract may reduce the water intake of hyperlipidemic albino rats.

The body weight gain of different groups of rats showed that hyperlipidemic group gained higher body weight due to high fat diet (cholesterol) used to induce hyperlipidemia in the rats that increased energy intake and energy storage [20].

When hyperlipidemic rats were given stevia sweetener at doses of 200,300, 400 and $500 \mathrm{ppm} / \mathrm{kg}$ b. wt then their body weight gain decreased. The decrease in body weight gain was due to capability of stevioside in stevia extract that decreased the food intake of rats. Furthermore, stevioside may also reduce the body weight gain by decreasing the glucose level and promote insulin sensitivity [23]. Another reason for the decrease of body 
Table 4 Mean values for serum lipid profile (mg/dL) of normal and hyperlipidemic rats after 8 weeks

\begin{tabular}{lllllll}
\hline Experimental groups & Total cholesterol & $\mathrm{HDL}$ & $\mathrm{LDL}$ & VLDL & LDL/HDL & Triglycerides \\
\hline $\mathrm{N}_{0}$ & $129.05 \pm 6.84 \mathrm{~b}$ & $41.52 \pm 2.54 \mathrm{a}$ & $35.34 \pm 2.78 \mathrm{~b}$ & $22.18 \pm 4.7 \mathrm{~b}$ & $0.85 \pm 0.42 \mathrm{~b}$ & $103.9 \pm 4.83 \mathrm{~b}$ \\
$\mathrm{H}_{0}$ & $150.55 \pm 7.83 \mathrm{a}$ & $37.04 \pm 3.74 \mathrm{~d}$ & $55.49 \pm 3.88 \mathrm{a}$ & $26.21 \pm 6.7 \mathrm{a}$ & $1.49 \pm 0.73 \mathrm{a}$ & $107.9 \pm 5.88 \mathrm{a}$ \\
$\mathrm{H}_{1}$ & $125.22 \pm 5.91 \mathrm{c}$ & $39.76 \pm 4.34 \mathrm{c}$ & $33.02 \pm 4.79 \mathrm{c}$ & $21.22 \pm 5.7 \mathrm{c}$ & $0.83 \pm 1.22 \mathrm{c}$ & $102.13 \pm 6.89 \mathrm{c}$ \\
$\mathrm{H}_{2}$ & $121.63 \pm 6.81 \mathrm{~d}$ & $40.13 \pm 4.74 \mathrm{bc}$ & $30.92 \pm 4.72 \mathrm{~d}$ & $20.72 \pm 8.7 \mathrm{~d}$ & $0.77 \pm 1.42 \mathrm{~d}$ & $101.12 \pm 6.71 \mathrm{c}$ \\
$\mathrm{H}_{3}$ & $116.17 \pm 5.89 \mathrm{e}$ & $41.14 \pm 4.38 \mathrm{ab}$ & $27.82 \pm 4.40 \mathrm{e}$ & $20.56 \pm 7 . \mathrm{de}$ & $0.67 \pm 1.50 \mathrm{e}$ & $99.11 \pm 6.54 \mathrm{~d}$ \\
$\mathrm{H}_{4}$ & $110.56 \pm 5.81 \mathrm{f}$ & $42.02 \pm 4.39 \mathrm{a}$ & $22.77 \pm 4.36 \mathrm{f}$ & $19.33 \pm 5.9 \mathrm{e}$ & $0.54 \pm 1.66 \mathrm{f}$ & $98.62 \pm 7.22 \mathrm{~d}$ \\
\hline
\end{tabular}

Values with different superscript letters along the column differ significantly $(P<0.05)$

$H D L$ High density lipoprotein, $L D L$ Low density lipoprotein, VLDL Very low density lipoprotein

$\mathrm{N}_{0}=$ Basal diet and distilled water

$\mathrm{H}_{0}=$ High cholesterol diet and distilled water

$\mathrm{H}_{1}=$ High cholesterol diet and distilled water with $200 \mathrm{ppm}$ aqueous stevia leaf extract

$\mathrm{H}_{2}=$ High cholesterol diet and distilled water with $300 \mathrm{ppm}$ aqueous stevia leaf extract

$\mathrm{H}_{3}=$ High cholesterol diet and distilled water with $400 \mathrm{ppm}$ aqueous stevia leaf extract

$\mathrm{H}_{4}=$ High cholesterol diet and distilled water with $500 \mathrm{ppm}$ aqueous stevia leaf extract

weight gain was due to stevioside ability to decrease the fat absorption and lipogenic enzymes and increase the fat excretion [24]. The results of current research are in line with [25-27] who found that there is a positive association between the decrease of body weight gain and dose of stevioside given to the rats. The body weight of rats decreased by increasing the concentration of stevioside in their diets.

The results of total cholesterol levels of different groups of rats depicted that $\mathrm{TC}$ level of $\mathrm{H}_{0}$ (hyperlipidemic group) had highest value. Conversely, addition of stevia aqueous extract at different levels lowered the TC levels in $\mathrm{H}_{1}, \mathrm{H}_{2}, \mathrm{H}_{3}$ and $\mathrm{H}_{4}$. Stevia aqueous extract contained stevioside that significantly lowered total cholesterol level due to its ability to increase the bile acid excretion by preventing reabsorption from small intestine through disruption of micelle formation of bile acid. The increase in excretion of bile acid and cholesterol activates cholesterol $7 \alpha$-hydroxylase that enhances the conversion of liver cholesterol to bile acid thus resulting in cholesterol reduction [28]. The present research is in accordance with [22, 29-31] according to them mechanism for reducing cholesterol level is due to the stevioside which binds the biliary or dietary cholesterol in the colon and increases the fecal excretion of the bile acids. The increased action of 3-hydroxy-3-methylglutaryl CoA reductase (HMGCoA) may stimulate the hepatic cholesterogenesis.

The data presented in Table 4 shows that concentration level of stevia supplementation had significant factor in lowering triglycerides in hyperlipidemic rats. In current research the increased level of triglycerides in $\mathrm{H}_{0}$ might be due to enhanced expression of enzymes including acetyl-coenzyme A carboxylase and fatty acid synthase, involved in TG synthesis. Moreover, malic enzyme was increased that supplies NADPH for the synthesis of long-chain fatty acids.

While in hyperlipidemic rats administrated with stevia aqueous extract, the TG levels decreased due to stevioside (major glycoside in stevia) that enhance the activity of lipase enzyme produced by liver that resulted in catabolism of lipids. Low concentration of triglycerides may also due to inhibition of dietary lipid absorption in the intestine by reducing micellar solubilization of cholesterol and by increasing excretion of TG via feces [32]. The hypolipidemic property of stevia might also be explained by interaction between stevia consumption and activation of peroxisome proliferators-activated receptors (PPARs). PPARs as a regulatory factor in lipogenesis process activate the expression of the lipoprotein lipase (LPL) and apo C-II genes as well as the hepatic uptake and etherification of free fatty acids, along with increasing mitochondrial free fatty acid oxidation [30]. The results of present research are also confirmed by the research works of $[22,26,27,33]$ who found that stevioside significantly lowered the triglyceride level as compared to untreated rats due to stevioside in stevia that reduced the activity of acetyl-coenzyme A carboxylase and fatty acid synthase.

The mean values for high density lipoprotein (HDL) levels of hyperlipidemic rats illustrated that lowest HDL level was observed in hyperlipidemic group and highest value of $\mathrm{HDL}$ was determined in $\mathrm{H}_{4}$. According to findings of present research the increase in the HDL levels of hyperlipidemic rats received stevia aqueous extracts at different levels was due to stevioside in stevia aqueous extract that improved the HDL level as compared to untreated rats. HDL (good form of lipid profile) is involved in transfer of cholesterol from tissues and arteries back to liver, thus reduced deposited cholesterol in the endothelium by retrieving cholesterol from peripheral cells and other lipoproteins to the liver for excretion in the bile and prevented LDL accumulation in the walls of the arteries [22, 32, 33]. Furthermore, [22, 26] found that stevia aqueous extract increased the HDL level in albino rats due to the elevation in the lecithin cholesterol acyl transferase (LCAT) activity which may attribute to the blood lipids regulation. 
Low density lipoprotein (LDL) levels of different groups of rats demonstrated that stevia aqueous extract decreased the LDL levels in hyperlipodemic rats. The stevioside in stevia aqueous extract significantly lowered the LDL levels in hyperlipidemic rats by up regulating LDL receptor. The increase in the LDL receptor improves the uptake of low density lipoprotein cholesterol from the blood circulation $[33,34]$. The findings of current research are in agreement with the studies of $[1,22]$ who found that stevia aqueous extract and Portulaca oleracea L. stem lowered the LDL level in rats because stevioside in stevia aqueous extract increase the LDL receptor and modulate cholesterol metabolism.

Very Low density lipoprotein (VLDL) levels of hyperlipidemic rats decreased after the administration of stevia aqueous extract at different dose levels due to glycoside (stevioside) in stevia extract that lowered the VLDL levels in hyperlipidemic rats. The results of present research work are in line with the work of [20,33] who demonstrated that stevioside and solanum species (egg plant) significantly decreased the VLDL. Similary, [34] depicted that methanolic leaf extract of Stevia rebaudiana significantly decreased the VLDL-C levels in alloxan induced diabetic mice. Furthermore, $[22,35]$ illustrated that stevia aqueous extract and Portulaca oleracea L. stem lowered the VLDL level in rats.

The mean values for LDL/HDL ratios (Table 4) in hyperlipidemic rats demonstrated that the highest value of LDL/HDL ratio was determined in hyperlipidemic group. While, LDL/HDL ratios decreased in hyperlipidemic rats received stevioside present in stevia aqueous extracts. The results of current research are in accordance with the findings of $[22,36]$ who found that stevia aqueous extract and two carotenoids (lycopene and $\beta$-Carotene) supplementation lowered the LDL/HDL ratio in albino rats.

\section{Conclusions}

The current research confirms that aqueous extract from stevia leaves may decrease the body weight gain, serum cholesterol, triglycerides, low density lipoprotein, very low density lipoprotein levels and LDL/HDL ratios. On the other hand, it improved the high density lipoprotein level of hyperlipidemic rats compared with untreated rats after eight weeks study period. It is concluded that aqueous extract of stevia with concentration $500 \mathrm{ppm} / \mathrm{kg}$ body weight of rats showed best results of all the parameters determined. It is confirmed from the results that stevia extract has hypolipidemic effects in albino rats. Nowadays obesity and hyperlipidemia are major health problems worldwide. As the diet of Pakistani population contained high amount of fat that's why they are also facing health issues like obesity, hyperlipidemia and cardiovascular diseases. Therefore aqueous extract from Stevia leaves could be used as natural anti-hyperlipidemic drug for the treatment of hyperlipidemia and its associated complications. From the present research as it is proved that Stevia rebaudiana Bertoni leaves are non-toxic and safe for animals so it could be used for humans as part of their diet.

\section{Abbreviations}

BWG \%: Body weight gain percentage; HDL: High density lipoprotein; LDL: Low density lipoprotein; TC: Total cholesterol; TG: Total triglycerides; VLDL: Very low density lipoprotein

\section{Acknowledgments}

The authors are thankful to the Institute of Home and Food Sciences, Government College University Faisalabad Pakistan for providing research facilities to prepare this valuable document.

\section{Funding}

No financial support was received in this research work.

\section{Availability of data and materials}

Available on request.

\section{Authors' contributions}

UA conceptualized and performed the study; RSA provided the technical assistance and guided in the data collection. MSA and ZA helped to analyze the data and drafting the manuscript. SMH and $\mathrm{AH}$ helped in improving the manuscript to make it more valuable. All authors read and approved the final manuscript.

\section{Ethics approval and consent to participate}

Before doing the research, written informed consent was obtained from all fellows that participate in this experiment and ethical approval was obtained from Institutional Review Board Faculty of Science \& Technology, Government College University, Faisalabad, Pakistan. The procedure followed the instructions of Good Laboratory Practice (GLP).

Consent for publication

Not applicable.

Competing interests

The authors declare that they have no competing interests.

\section{Publisher's Note}

Springer Nature remains neutral with regard to jurisdictional claims in published maps and institutional affiliations.

\section{Author details}

'Department of Food Science, Nutrition \& Home Economics, Government College University, Faisalabad, Pakistan. ${ }^{2}$ Institute of Home and Food Sciences, Faculty of Science and Technology, Government College University, Faisalabad 38000, Pakistan. ${ }^{3}$ Department of Zoology, Government College University, Faisalabad 38000, Pakistan. ${ }^{4}$ Department of Food Science and Technology, Bahauudin Zakariya University, Multan 38000, Pakistan.

Received: 16 October 2017 Accepted: 3 July 2018

Published online: 27 July 2018

\section{References}

1. El-Newary SA. The hypolipidemic effect of Portulaca oleracea L. stem on hyperlipidemic Wister albino rats. Annals of Agricultural Sciences. 2016:61(1):111-24

2. Javed I, Rahman ZU, Khan MZ, Muhammad F, Aslam B, lqbal Z, Sultan JI, Ahmad I. Antihyperlipidaemic efficacy of Trachyspermum ammi in albino rabbits. Acta Vet Brno. 2009;78:229-36.

3. Anbazhagan M, Kalpana M, Rajendran R, Natarajan V, Dhanavel D. In vitroproduction of Stevia rebaudiana Bertoni. EJFA. 2010;22(3):216-22. 
4. Brahmachari G, Mandal LC, Roy R, Mondal S, Brahmachari AK. Stevioside and related compounds-molecules of pharmaceutical promise: a critical overview. Arch Pharm Chem Life Sci. 2011;(1):5-19.

5. Lemus-Mondaca R, Vega-Galvez A, Zura-Bravo L, Ah-Hen K. Stevia rebaudiana Bertoni, source of a high-potency natural sweetener: a comprehensive review on the biochemical, nutritional and functional aspects. J Food Chem. 2012;132:1121-32

6. Stoyanova S, Genus J, Heideg E, Den Ende W. The food additives insulin and stevioside counteract oxidative stress. Int J Food Sci Nutr. 2011;62:207-14.

7. Ferrazzano GF, Tiziana Cantile T, Brunella Alcidi B, Coda M, Aniello Ingenito A, Armando Zarrelli A, Fabio GD, Pollio A. Is Stevia rebaudiana Bertoni a non cariogenic sweetener? A Review Molecules. 2016;21:1.38. https://doi.org/10. 3390/molecules21010038.

8. Sirisha K, Shivani J. Antihyperglycemic and Antihyperlipidemic activities of new Polyherbal formulations. JAPBC. 2014;3(1):189-98.

9. Ritu M, Nandini J. Nutritional composition of Stevia rebaudiana, a sweet herb, and its hypoglycaemic and hypolipidaemic effect on patients with non-insulin dependent diabetes mellitus. J Sci Food Agric. 2016;96(12):4231-4.

10. Kujur RS, Singh V, Ram M, Yadava HN, Singh KK, Kumari S, Roy BK. Antidiabetic activity and phytochemical screening of crude extract of Stevia rebaudiana in alloxan-induced diabetic rats. Pharm Res. 2010;2(4):258-63.

11. Abou-Arab AE, Abou-Arab AA, Abu-Salem MF. Physico-chemical assessment of natural sweeteners steviosides produced from Stevia rebaudiana Bertoni plant. Afri J Food Sci. 2010;4:269-81.

12. AOAC. Official methods of analysis of the Association of Official Analytical Chemists 17th Ed.; AOAC International, Gaithersburg, MD; 2000.

13. Iqbal Z, Ashraf T, Khan AA, Hussain R, Mudassar M. Antihyperlipidemic efficacy of cinnamon in albino rats. Asian J Agri Biol. 2016;4(1):8-16.

14. Uchida K, Satoh T, Ogura Y, Yamaga N, Yamada K. Effect of partial ileal bypass on cholesterol and bile acid metabolism in rats. Yanago. Acta Med Austriaca. 2001:44:69-77.

15. Stockbridge H, Hardy RI, Glueck CJ. Photometric determination of cholesterol (CHOD-PAP method). Ecoline ${ }^{\circledast}$ 2S, Merck KGaA, 64271 Darmstadt, Germany. J Lab Clin Med. 1989;114(2):142-51.

16. Annoni G, Botasso BM, Ciaci D, Donato MF, Tripodi A. Liquid triglycerides (GPO-PAP). Lab J Res Lab Med. 1982:9:115.

17. Assmann G. HDL-cholesterol precipitant. Randox labs. Ltd. Crumlin co., Antrim, N. Ireland. Internist. 1979:20:559.

18. Friedewald WT, Levy RI, Fredickson DS. Estimation of the concentration of low-density lipoprotein cholesterol in plasma, without use of the preparation ultracentrifuge. Clin Chem. 1972;18:499-502.

19. Steel RGD, Torrie JH, Dickeyi D. Principles and Procedures of Statistics A biometrical approach. 3rd ed. New York: McGraw Hill Book Co. Inc 1997. p. 336-52.

20. Onyeike EN, Monanu MO, Okoye CN. Changes in the blood lipid profile of wistar albinorats fed rich cholesterol diet. Annals Biological Research. 2012;3(11):5186-91.

21. Robarts MW, Wright JT. Sweetness without sugar. Dimeus Dent Hyg. 2010;8:58-61.

22. Abo Elnaga NIE, Massoud MI, Yousef MI, Mohamed Hayam A. Effect stevia sweetener consumption as non-caloric sweetening on body weight gain and biochemical's parameters in over weight female rats. Annals of Agricultural Sciences. 2016:61(1):155-63.

23. Rajasekar P, Anuradha CV. Effect of L-carnitine on skeletal muscle lipids oxidative stress in rats fed high-fructose diet. Exp Diabetes Res. 2007;1:72-4

24. Rains TM, Agarwal S, Maki KC. Antiobesity effects of green tea catechins: a mechanistic review. J Nutr Biochem. 2011;22:1-7.

25. Abd El-Razek AM, Massoud MI. Biological evaluation of aqueous extract of Stevia rebaudiana leaves. Egypt J Food Sci. 2012;40:47-61.

26. Akbarzadeh S, Eskandari F, Tangestani H, Bagherinejad ST, Bargahi A, Bazzi P, Daneshi A, Sahrapoor A, O'Connor WJ, Rahbar AR. The effect of Stevia rebaudiana on serum omentin and visfatin level in stz-induced diabetic rats. J diet Suppl. 2015;12(1):1-12.

27. Assaei R, Mokarram P, Sanaz Dastghaib S, Darbandi S, Darbandi M, Fatemeh Zal F, Akmali M, Omrani GHR. Hypoglycemic effect of aquatic extract of Stevia in pancreas of diabetic rats: PPARy-dependent regulation or antioxidant potential. Avicenna J Med Biotech. 2016;8(2):65-74.

28. Curry L, Roberts A. Subchronic toxicity of rebaudioside a. Food Chem Toxicol. 2008:46:S11-20.

29. Hossain MS, Alam MB, Asadujjaman M, Islam MM, Rahman MA, Islam MA, Islam A. Antihyperglycemic and anti hyperlipidemic effects of different fractions of stevia rebaudiana leaves in alloxan-induced diabetic rats. Int J Pharm Sci Res. 2011;2(7):1722-9.

30. Akbarzadeh S, Eskandari F, Tangestani H, Bagherinejad ST, Bargahi A, Bazzi P, Daneshi A, Sahrapoor A, WJ O'C, Rahbar AR. The effect of Stevia Rebaudiana on serum Omentin and Visfatin level in STZ-induced diabetic rats. J Diet Suppl. 2014; https://doi.org/10.3109/19390211.2014.901999.

31. Brijesh K, Kamath M. Experimental evaluation of anti-hyperglycemic and hypolipidemic effects of stevia rebaudiana, Anacardium occidentale on wistar rats. Int J Basic Clin Pharmacol. 2016;5(6):2463-7.

32. Sukla R, Gupta S, Gambhir JK. Antioxidant effect of aqueous extract of the bark of Ficus bengalensis in hypercholsterolaemic rabbits. J Ethanopharmacol. 2004;92:47-51.

33. Rajesh S, Rajesh Y, Elangovan M. Study of effect of Stevia rebaudiana berton on oxidative stress in type-2 diabetic rat models. Aging Pathol. 2012;2:126-31.

34. Singh S, Garg V, Yadav D. Antihyperglycemic and antioxidative ability of stevia rebaudiana (bertoni) leaves in diabetes induced mice. Int J Pharm Sci. 2013;5(2):297-302.

35. Prasad BS, Srinivasan KK, Harindran J. Chonemorpha Fragrans (moon) Alston-an effective anti-hyperglycemic and anti-hyperlipidemic agent in Streptozotocin Nicotinamide induced diabetic rats. Int J Pharm Sci Res, 2016;7(3):1149-55.

36. Salem AS. Effect of two carotenoids (lycopene and $\beta$-carotene) supplementation on hyperlipidemia and lipid peroxidation in experimental albino rats. J high institute of. Public Health. 2015:45(1):1-7.

\section{Ready to submit your research? Choose BMC and benefit from:}

- fast, convenient online submission

- thorough peer review by experienced researchers in your field

- rapid publication on acceptance

- support for research data, including large and complex data types

- gold Open Access which fosters wider collaboration and increased citations

- maximum visibility for your research: over $100 \mathrm{M}$ website views per year

At BMC, research is always in progress.

Learn more biomedcentral.com/submissions 